Article

\title{
Are They Neck and Neck in the Affordable Housing Policies? A Cross Case Comparison of Three Metropolitan Cities in China
}

\author{
Xiang Cai ${ }^{1}$, Chin-Chang Tsai ${ }^{2}$ and Wei-Ning Wu ${ }^{3, *}$ \\ 1 School of Economic, Political and Policy Sciences, The University of Texas at Dallas, 800 W. Campbell Rd, \\ Richardson, TX 75080, USA; xiang.cai@utdallas.edu \\ 2 School of Public Affairs, Arizona State University, Phoenix, AZ 85004, USA; ctsai24@asu.edu \\ 3 Institute of Public Affairs Management, National Sun Yat-sen University, Gushan District, \\ Kaohsiung 80424, Taiwan \\ * Correspondence: weiningwu@mail.nsysu.edu.tw; Tel.: +886-75252000 (ext. 4917)
}

Academic Editors: Hongbo Liu, Sizhong Sun and Iain Gordon

Received: 24 November 2016; Accepted: 20 March 2017; Published: 1 April 2017

\begin{abstract}
Many municipal governments have adopted affordable housing policies to benefit people whose socio-economic status is not commensurate with the price of housing. However, the effects and the functions of these policies in the city on sustainable development and living remains limited. Using a comparative case study, this study explores the characteristics and effects of affordable housing policies in three metropolitan cities in China: Beijing, Tianjin, and Guangshou. This study finds that these cities have their unique affordable housing policies and have experienced various challenges in implementing those policies. Conclusions and implications for other cities in China are addressed.
\end{abstract}

Keywords: affordable housing; sustainability; poverty; inequality; China

\section{Introduction}

Affordable cost of living is viewed as a social aspect of sustainable development, and governments have developed affordable housing programs to provide low- to moderate-income households with housing units at lower costs to eschew any social segregation and instability [1-3]. The comprehensive goals of affordable housing are to ensure the supply of good-quality housing units, enhance the affordability and availability of existing housing, help households build wealth, relieve families' burden, promote balanced metropolitan growth, and link housing with essential supportive services [4-6].

Current studies have paid more attention to case studies, which explore the practical experience and lessons of affordable housing programs in various counties and cities [7-10]. Some studies discuss topics related to the role of federal government in the responsibilities and implementation of affordable housing programs [11]. For example, in the United States, the diminishing federal support from political leaders and legislators for affordable housing policy has made the implementation of related affordable housing plans more difficult $[12,13]$. Although the responsibility for implementing affordable housing is being transferred to the states and, particularly, to local actors, the financial support from federal government has still influenced the development of affordable housing programs $[6,7,14]$.

The new era of post-federal housing innovation has shifted away from the nation's capital toward the state capitals, city halls, and nonprofit organizations (NPOs) $[12,15,16]$. Similar situations have been prevailing in China. In China, significant changes have taken place in the urban housing system since the early 1990s, and market-oriented housing reforms have improved both quality and living 
space for urban residents. On the other hand, the marketization of the housing system has engendered a real-estate boom, leading to dramatic housing-price inflation, a booming job market, and a lack of housing affordability $[17,18]$.

Moreover, affordable housing plays the role of catalyst for urban sustainable development [19]. However, the ongoing process of urbanization and industrialization throughout the decade has aggravated the housing affordability problem. Policy makers at different levels are striving to search for effective ways to implement affordable housing programs efficiently and provide affordable housing for low-income groups. The central government has merely provided guidelines and relatively small loans as an initial source of financial support, while the majority of the large funds required for the implementation of the public housing provisions must be raised solely by local governments [20].

Many cities in China have encountered housing affordability problems, and divergent opinions on the planning and implementation of affordable housing policies [21]. Beijing, Tianjin, and Guangzhou are the major cities selected for this comparative study. These three municipalities are significant examples of public policy and administrative reform and are representative of many Asian countries $[4,9,17]$. In addition, another reason for choosing these cases is the similarity of their economic and demographic features: the cities are major domestic or international immigrant cities with prosperous financial and service industries. The dataset consists of those cities' aggregated data, which are derived from the China Real Estate Statistics Yearbook [22] and China Statistical Yearbook [23].

Much has been written about the case studies of affordable housing policies in various countries. However, very few studies discussed the cases of China's municipalities. This study conducts a comparative case study exploring the main affordable housing policy issues of three major municipalities, and puts forward suggestions for current affordable housing program development in China.

\section{Affordable Housing: An Overview}

\subsection{Definition of Affordable Housing}

Numerous countries experienced the problem of housing affordability in the past decades. The efforts to provide sufficient and decent affordable housing have been the policy priority of numerous governments. The concept of "affordable housing" has been widely used in current studies. However, thus far there is no comprehensive and agreeable definition of affordable housing.

Maclennan and Williams [11] argued that affordability is concerned with securing some given standards of housing (or different standards) at a price or rent which does not impose, in the eye of some third party (usually government), an unreasonable burden on household incomes. In this sense, consumers should be able to maintain a socially-acceptable standard of living after they pay housing costs [5]. The City Council of Calgary defines affordable housing as housing that adequately suits the needs of low- and moderate-income households at costs below those generally found in the market. Different schemes, such as emergency shelters, transitional housing, social or subsidized housing, and affordable housing ownership, are intended to help citizens alleviate housing costs and maintain adequate standard of living [24].

The U.S. Department of Housing and Urban Development (HUD) asserts that housing affordability refers to 30 percent of income spent on housing [6]. Therefore, housing expenditures that exceed 30 percent of household income have been considered a housing affordability problem. To work out solutions to housing affordability problems, the HUD, defines affordable housing as "the housing that costs no more than 30 percent of a household's monthly income." [4,25] In addition, HUD utilizes the indicator of Area Median Income (AMI), the median household income for a selected area, to determine whether households are eligible for some specific public programs [26,27]. Thus, affordable housing policy places a focus on low-income groups $(<50 \% \mathrm{AMI})$ to moderate-income families $(80 \%$ to $120 \%$ AMI) who are suffering from housing affordability problems [16]. 
In the United Kingdom, the Department for Communities and Local Government specifies the characteristics of affordable housing according to the definition of affordability as income ratio (OTI), availability of alternatives, and sustainability. The major features of affordable housing are as follows: (1) Affordable housing aims to provide for specific eligible households whose needs cannot be met in the market. Its scheme includes social rented and intermediate housing; (2) Based on the local house-to-income ratio, affordable housing intends to fulfill the dwelling needs of eligible households at a sufficiently low cost; (3) Affordable housing pays attention to retaining sufficient housing units in order to provide housing for future eligible households; (4) Subsidies for alternative housing provisions should be maintained and renewed as long as restrictions are still in place $[28,29]$.

The Chinese government provides affordable housing merely for low- to lower-middle-income permanent residents/families that have been registered under the city resident system (hukou). Therefore, one income level is enforced as the cut-off for verification of eligibility for affordable housing. According to the Beijing Municipal Commission of Housing and Urban-Rural Development (BMCHURD), an affordable housing applicant who is registered in the Beijing Municipal Resident System for at least three years should be earning less than 60,000 RMB annually, and should possess no more than 480,000 RMB in assets. Moreover, the average of the applicant's living area in a household has to be less than 10 square meters [30-32]. Although these requirements may be adjusted based on the situations of metropolitan areas in China, income, assets, and living area are the major standards [33].

\subsection{Benefits of Affordable Housing}

Affordable housing programs have benefited local residents and regional social sustainability. Local residents are able to fulfill their dwelling needs with acceptable housing expenses, and the community is able to gain more resources and attract more people to live and invest. These vital benefits are as follows:

\subsubsection{Fiscal and Economic Benefits}

Fiscal and economic benefits of affordable housing programs are the main concerns of citizens because they are related to the cost for taxpayers. In most cases, public managers try to persuade taxpayers of the fiscal and economic benefits of affordable housing programs through a cost-benefit analysis of such programs [31]. Job-creation and sales taxes are the most common fiscal and economic benefits. For example, the National Association of Home Builders (NAHB) estimates that more than 120 jobs will be created, on average, during a project's construction of 100 affordable housing units. The ripple effect is maintained long after the homes are occupied, that is, these new units can support as many as 30 new jobs in a wide array of industries, including retail, healthcare, and local government [34].

Moreover, affordable rent and mortgage payments can increase residual income of households, and citizens are able to increase their purchasing power after meeting necessary housing costs. Thus, local businesses are more likely to gain from increased sales as a result of the availability of affordable housing [35]. Instead of adding costs to the taxpayer, affordable housing actually saves taxpayer money by reducing demand for other expensive government services, including settlement of homeless, health and other programs. However, some are still unsatisfied with the outcome of affordable housing programs because they think they do not benefit from those programs. For example, one major concern is about the increasing tax burden [36].

\subsubsection{Social Welfare Benefits}

Affordable housing has the function of social sustainability. Affordable housing not only can enhance positive education related outcomes by reducing the need to relocate for unprivileged households, but also can improve resident health by reducing exposure to environmental hazards and the need for more resources to pay for health expenses and food [25]. Affordable housing can help 
stabilize families with reasonable costs of dwelling, avoiding the disruption of children's education, the interruption of a child's learning environment, and a sense of impermanence in life [37].

Well-constructed and well-maintained affordable housing can reduce health problems associated with poor-quality housing. Families are usually forced to live in substandard housing when they have few affordable housing options. These substandard units are more likely to put residents at risk of lead poisoning, asthma, and accidental injury [38]. Based on a survey of 2012 household expenditures, it was found that low-income households that spend more than half of their income on housing costs spend less on food and healthcare due to the severity of the housing-cost burden when compared to similar families spending 30 percent or less of their income on housing [39]. In addition, families suffer from insufficient resources for other essential needs, such as food and healthcare, if they have to pay excessive amounts of income for housing. Access to affordable housing, therefore, can enable families alleviate family spending $[35,40]$.

\subsubsection{Integration and Equity Benefits}

It is well known that affordable housing developed along with social and economic inclusivity can seamlessly integrate lower-income residents into their neighborhood and the broader community [12]. Affordable housing located in integrated communities can be a platform for improving quality of life and creating neighborhoods of opportunity, by increasing sustainability in communities through strong infrastructure and green development, supporting partnerships with residents to create inclusive and equitable planning and development, and last but not the least, encouraging collaboration to address the integrated, complex needs of community members [19]. Furthermore, these integration benefits can ultimately lead to the achievement of equity, as those benefits provide an opportunity with lower- income and underprivileged groups to have a say in the sustainable development of the communities in which they live.

\subsection{Challenges of Affordable Housing}

There are still some significant challenges and barriers to the sustainable development of affordable housing. Land supply is one main issue that needs to be solved before planning the provisions for affordable housing [41]. Housing development is mainly influenced by land use and planning, and many cities in the process of rapid urbanization are struggling to balance the supply of large land parcels to affordable housing development and city renewal and gentrification. Due to budgetary cutbacks and stringent requirements of governmental regulations, budget restriction is viewed as a major challenge to the further promotion of affordable housing. When there are only limited public funds in enhancing projects related to affordable housing, public managers are unable to sustain and serve residents' needs for dwellings at affordable costs.

There are multiple obstacles to the creation of affordable housing, such as conflicts between public and private sectors, cost control, lack of building experience and capacity, and regulation specifications $[11,19]$. While some huge strides have been made in promoting affordable housing and reducing housing costs for underprivileged families, there are still a variety of risks and local concerns related to cost-benefit arguments for these enormous projects, such as segregation and issues of criminality when lower-income families move into local communities [18].

\section{Development of Affordable Housing Policies in China}

The housing market had not grown well in China's urban areas in the 1990s. Housing was considered to be one of the urban welfare issues, and was allocated by government institutions and state-owned enterprises in major cities [33]. Thus, residents in urban areas could live in houses assigned by public officials for free or with nominal rents, the cost of which was defined according to the standard of the resident's work status [42].

With the market-oriented reforms and the failure of the publicly-allocated housing system, the State Council of China issued the Decision on Deepening the Urban Housing Reform in 1994 
to build a comprehensive framework for housing reform as well as a housing market. Moreover, two affordable housing programs were introduced in the Decision: The Economic and Comfortable Housing (ECH) program and The Housing Provident Fund (HPF). The ECH program was designed to provide housing for low- to lower-middle-income households by limiting the prices of affordable housing projects. The HPF program was established to combine both social savings and private savings for potential home buyers [20]. These supply-side and demand-side programs aimed at establishing a viable housing market in which households could purchase houses from the property market [30]. In essence, this was the first time affordable housing policy was written into official documents of the Chinese government.

To enhance the role of local government in service delivery of affordable housing, a string of decentralized guidelines that considered local conditions were adopted for the implementation of affordable housing programs. For example, the ECH program, the HPF program, and the Cheap Rental Housing (CRH) program were established for the extreme-low- and low-income groups. However, affordability remained a problem for the majority; what was worse, this led to social instability and political problems. Therefore, the State Council of China issued the Notification and Opinions on Adjusting the Housing Supply Structure as well as Stabilizing Housing Prices, which included "Six Property Control Policies" in 2006. The purpose was to involve the 70/90 Principle and the Limited Priced Housing Policy (LPHP) as complements to the ECH program. The 70/90 Principle stipulated that at least 70 percent of the units of all new housing construction projects should not be larger than 90 square meters.

The LPHP specified that ECH project developers should earn no more than 3 percent marginal profits to ensure that discounted prices (usually half) will be offered [43]. These initiatives resulted in three above-mentioned programs of affordable housing policy, which are the ECH program, the HPF Program, and the CRH program. Since 2013, there has been a major shift in affordable housing policies. Several major cities, including Beijing, Guangzhou, and Shenzhen, stopped developing new $\mathrm{ECH}$ projects in compliance with the announcement of the Ministry of Housing and Urban-Rural Development (MOHURD). In the meantime, the Public Rental Housing was enforced as the new form of affordable housing program, in combination with the existing CRH program.

\section{Data and Methodology}

This research utilizes a systematic analysis of three cities over 11 years (2000-2010), with an emphasis on comparing general and distinctive characteristics of affordable housing programs in those three cities. As noted above, data were gathered from the China Real Estate Statistics Yearbook [22] and China Statistical Yearbook [23]. A series of variables is included in the comparative analysis, including the absolute amount of investment in housing and affordable housing projects and several ratio indicators that manifest more accurate trends or opportunities for investment.

\section{Case Study}

\subsection{Beijing City}

Beijing is the capital city of China, which is one the most industrial, densely-populated metropolises in China. More than 19 million people reside in the city, including almost 12 million permanent residents registered in the Hukou system and 7 million migrant residents [44]. In addition to an attractive city for migrants and entrepreneurs, the Beijing Municipal Government seeks to offer affordable housing and fulfills the dwelling needs of local residents [45]. However, residents in Beijing face severe housing affordability problems due to the highest housing prices and the most rapid rate of price inflation. As a result, the Beijing Municipal Government has been criticized in that it fails to regulate exponential price inflation.

To cope with housing issues and follow the housing guidelines made by the central government, the Beijing Municipal Government has enforced a series of implementation plans. First, the land parcels 
for building affordable housing are granted administratively by the local government to developers without any charge [46]. The land, of course, has to be used for the development of affordable housing units. The price of affordable housing in Beijing is set as the cost of development, plus taxes and a 3 percent profit cap for developers. The regulated price also has to be endorsed by the municipal government based on the specifics of the housing development project and its location. Variations in housing prices are based upon the floor level and orientation; however, adjustments cannot exceed 3 percent and the sum of charges for the whole building must remain the same [3]. In contrast to full ownership of market-priced housing, limitations are placed on the ownership of affordable housing. Municipal governments also set up fixed prices for property management, which are much lower than that for market-priced housing.

In terms of the investment during the last 12 years in Beijing, the annual investment continuously increased for the first several years from 1999 to 2004, and then decreased for the following four years from 2005 to 2008. While there was a sudden increase in investment in 2009, the investment in Beijing sharply shrank by over 20 percent in 2010. The investment trends mainly indicate the response to the shifts in central government guidelines. A further look at affordable housing in Beijing shows that the size of affordable housing units is not limited in Beijing. Since the supply of land is constrained by the municipal authority, the number of housing units is lower when they are unnecessarily large [45]. On the one hand, these large units cause unaffordability in the total price for eligible groups; on the other hand, oversized units lead to insufficient numbers in the provision of affordable housing. In addition, numerous approved applicants do not belong to the targeted groups due to ambiguous income limitations for eligible households. As a result, many people at higher levels of income are able to obtain affordable housing because of the lack of a reliable system for differentiating the rich from the poor [47].

\subsection{Tianjin City}

Tianjin is one of the four directly-controlled municipalities in China under direct administration of the central government. Located in northern coastal China and close to the capital Beijing, this city also has a high population density (over 15 million people), ranking fourth in China after Chongqing, Shanghai, and Beijing. The affordability index of the city indicates that the city has a severe housing affordability problem, but such problem lacks sufficient investigation.

To decrease the housing affordability gap among local residents, the Tianjin Municipal Government has invested around 20 billion RMB and provided 1000 hectares of land to ensure provision of affordable housing. By the end of 2010, the coverage of affordable housing had reached 20 percent of the total housing sector in the city, which was the policy goal of state guidelines from the central government in the 12th Five-Year Plan (2011-2015). By 2010, the municipal government had constructed more than 24 million square meters of new affordable housing and provided, overall, 410,000 eligible households. These achievements were mainly derived from its long-term strategy of planning, construction and maintenance management, not from the mere focus on the scale of construction. Moreover, the municipal government in Tianjin was one of the pioneers that established schemes of affordable housing and specified income criteria and other eligibility thresholds.

In addition, public participation in the allocation process is the main characteristic of the affordable housing provisions. Local representatives and public notaries are involved in the process of housing allocation quarterly. Based on the features of investment in affordable housing in Tianjin, the total public funding resources have been mainly increased over the last decades, except for 2004 and 2005. Because of the state policy shift towards promoting the housing market boom, the amount of investment has risen exponentially since 2007, even though other cities are still reluctant to further enhance their funding of affordable housing. Given the sufficiency of resources poured into affordable housing development, the coverage has been significant expanded (over 20 percent), and assists a great number of lower-income families in fulfilling their housing needs. 
Overall, there are two main issues regarding affordable housing provisions in Tianjin. First, the municipal government needs to fix current housing units. Second, location selection and concentration is another challenge in Tianjin. A majority of the existing affordable housing units are located in suburban or developing areas with substandard transportation and public services. Additionally, concentration is much more likely to cause segregation and other social problems, such as high crime rates of criminality and low rates of business investment.

\subsection{Guangzhou City}

Guangzhou is the capital city of Guangdong (Canton) Province and one of the five highly-developed National Central Cities. Along with its long history as a business and financial center in southern China, Guangzhou has been one of the most-developed cities in China since the economic reform of the late 1970s. At present, the permanent population living in Guangzhou is approximately 8.5 million, plus more than four million immigrants unregistered as permanent residents. According to the 2010 Census, more than 60 percent of the population lives in the central districts and over 26 percent resides in new districts, implying that over 11 million people are living in this metropolitan area.

Based upon the evidence of the 2012 China Household Financial Survey conducted by the Survey and Research Center, the national average rate of house-ownership is 80 percent. However, despite its economic development, the average rate of house-ownership in Guangzhou is 72.8 percent. This house-ownership ratio excludes the over four million non-permanent inhabitants.

Furthermore, Guangzhou is a pilot city for housing reform and affordable housing innovation, having consistently implemented new housing policies during the past two decades. The development of affordable housing in Guangzhou has some additional requirements, however, such as floor areas restricted to 60-65 Square Meters, a profit cap for developers (3 percent), land provision, and an income threshold for applicants. None of these units are permitted to be rented out in the market, or allowed to be part of any market transaction for five years after execution of the purchase contract. Even after the five-year constraint expired, the municipal government has the prior right to repurchase the units should applicants want to sell, and applicants who sold their units are required to pay a "land revenues" tax to obtain the full ownership of the properties for the transaction.

Although Guangzhou has been a pioneer city promoting affordable housing, investment was extremely low all through the 12 years. Even though the amount has continued increasing since 2008, the total investment was a mere sixth of that in Tianjin and less than one half of investment in Beijing. As a result of insufficient funding resources, the coverage of affordable housing in Guangzhou remains too limited to benefit a great number of residents. In addition to funding issues, land supply is far from sufficient for affordable housing development in this city. Despite the state having issued a mandatory notification, the municipal government remains unlikely to promote its affordable housing projects and enhance the provision.

\section{A Comparative Analysis of the Three Cities}

\subsection{Major Charactersitics and Effects of Three Cities' Affordable Housing Policies}

This research identifies the features of affordable housing in these major Chinese cities and evaluates the outputs of sustainable development, mainly in terms of housing issues. In all three cases, key factors include sufficient investment, long term strategies and public participation with consideration for local housing needs along with the central guidelines to advance their agenda (Table 1).

The presence of a comprehensive strategy in housing policy is the main prerequisite for ensuring sustainable development in affordable housing policy. The Tianjin Municipal Government establishes its overall long term plans for planning and maintenance management in affordable housing, which offer clear blueprints and main objectives in the development of affordable housing provision to both local authorities and residents in the city. 
Table 1. A Comparative Analysis of the Three Cities.

\begin{tabular}{|c|c|c|c|}
\hline & Beijing & Tianjin & Guangzhou \\
\hline $\begin{array}{l}\text { Response to Central } \\
\text { Government Guidelines }\end{array}$ & Strong & Strong & Weak \\
\hline $\begin{array}{l}\text { Condiseration for Local } \\
\text { Housing Needs }\end{array}$ & Weak & Strong & Weak \\
\hline Overall Strategy & $\begin{array}{l}\text { No, merely response to } \\
\text { central guidelines }\end{array}$ & $\begin{array}{l}\text { Yes, including planning, } \\
\text { construction, management }\end{array}$ & $\begin{array}{l}\text { No, and no significant } \\
\text { action on affordable } \\
\text { housing promotion }\end{array}$ \\
\hline Investment & $\begin{array}{l}\text { Shifting profoundly } \\
\text { in response to } \\
\text { central guidelines }\end{array}$ & $\begin{array}{l}\text { Shifting according to } \\
\text { central guidelines, } \\
\text { but with consideration of } \\
\text { local housing needs }\end{array}$ & $\begin{array}{l}\text { Insufficient; investment at } \\
\text { very low level }\end{array}$ \\
\hline Public participation & $\begin{array}{l}\text { No real participation } \\
\text { in housing policy }\end{array}$ & $\begin{array}{l}\text { Participation in } \\
\text { housing allocation }\end{array}$ & No participation \\
\hline Land Supply & $\begin{array}{l}\text { Striving to provide } \\
\text { sufficient land }\end{array}$ & $\begin{array}{l}\text { Sufficient but mostly in } \\
\text { remote areas }\end{array}$ & $\begin{array}{l}\text { Lack of land parcels } \\
\text { provided }\end{array}$ \\
\hline Unit Management & Oversized units & Oversized units & Housing units specified \\
\hline Funding Resources & $\begin{array}{l}\text { Public funding, unstable } \\
\text { budgeting sources }\end{array}$ & $\begin{array}{l}\text { Multiple funding platforms } \\
\text { established, but mainly from } \\
\text { public funding }\end{array}$ & Insufficient public funding \\
\hline
\end{tabular}

Based on these strategies, it is possible to further enforce specific programs in order to accomplish this mission, and to effectively evaluate the policy outputs and then modify implementation plans to comply with the established goals. The long-term strategies are not a series of documents that are published as circulation papers, but a volume of listed policy expectations and agendas aiming to examine ultimate outcomes. Without this long-term strategy, affordable housing policies are still subordinated to local economic policy, which merely aims to promote local gross domestic product (GDP), rather than being established as major projects for the enhancement of social justice.

Decreasing uncertainty of funding sources is the main issue to ensure affordable housing development, which implies that municipal authorities must place an prior emphasis on the implementation of affordable housing policies [24]. This is also one of the major measures that evaluate the incentives and performance of local governments on housing issues. Affordable housing development is well-known for its chronically slow construction, high cost and maintenance, large volume of investment in public facilities and infrastructure, and long-term capital turnover [21]. Thus, it is a huge challenge for local governments to maintain stable and sufficient public spending on these projects as well as to reduce their revenues from land transactions. Moreover, compared to the public budget, funding source initiatives are the more optimal option for municipal authorities to amplify their funding pools in affordable housing, even though this is still the preliminary phase of attracting social funding in China [17]. As the case of Tianjin City demonstrates, local governments that are in charge of their funding platform ought to take further advantage of resources to promote affordable housing construction and provision.

Two common issues are revealed among the three cities: land supply and location, and housing unit regulations. In policy documents, all affordable housing construction has established criteria for maisonettes; however, these rules have a low effectiveness in implementation. The number of larger units has been decreasing because of developers' pursuit of profit. As larger maisonettes are more likely to decrease costs of construction and increase the value of each unit, developers of housing construction prefer to build huge buildings to generate higher profits. In addition, these three cities confront the dilemma related to land scarcity. To maintain their revenues intact, they have employed various approaches. Main options are reducing land supply for affordable housing and developing housing projects located in remote and less prosperous areas to retain the high value land in the inner city. 
Finally, the comparison between these three cities identifies that citizen participation in the planning process of housing policy is viewed as an effective way to ascertain efficiency and equity. In addition to building up a "smart system" to verify whether or not the criteria are met by each application online, Tianjin has established an oversight mechanism for the process of housing allocation, and has made personal income information of eligible applicants available for public supervision. This participation may lead to an increase in trust between residents and city officials as their participation in oversight manifests a communal responsibility for sustainable development of affordable housing in the city. Moreover, citizen participation mechanisms encourage local residents to pay further attention to housing issues so as to strengthen the relations between local government and different inhabitant groups [48].

In light of the comparative analysis of the three cases, we are able to indicate the main features that have tremendous impacts on sustainable development in affordable housing policies. Affordable housing policies are still new in the Chinese housing sector. Based on the experience and lessons we learned from these three cases, further policy implications are needed to fulfill the purpose of improving policy effectiveness. As indicated by the results and analyses discussed above, strategies that involve the entire process of planning and implementing of affordable housing, public participation, and funding initiatives at local level are offered as the main clues to sustainably benefit unprivileged residents and lower their unaffordable housing costs in major Chinese cities during the rapid process of economic development and urbanization.

\subsection{The Comparison of Three Cities' Demographic and Economic Features}

The demographic and economic features of these cities during recent decades have similar characteristics. In Table 2, the population densities of the three cities are high, with more than ten thousand people per square mile. Tianjin is a special case because the Binhai New Area is a new semi-provincial district established in 2009. Even with the variations in the population of these cities, it is worth noting that the high population density would probably play a huge role in the demand for housing, including affordable housing. Household size in these cities is also similar. Families with two to three members represent the majority household size. With respect to housing price and housing affordability index, high prices of housing exert significant negative impacts on the housing affordability of local residents. Since housing prices in these cities are more than $\$ 270$ per square foot, housing is severely unaffordable (housing affordability index $>5$ ) for their population relative to household income. Hence, despite high economic development in these cities and the high income of their dwellers, it is believed that the three cities have high population density and severe housing affordability problems.

In Table 2, the household income is the average household income in the selected areas, and housing price in this table is the average housing price in each of the three cities. There are two reasons we use the average values to demonstrate the housing affordability crisis in this paper. First and foremost, the data source from China Real Estate Statistics Yearbook in China is based on a mean calculation rather than median values, and we don't have any data sources that reflect median values of housing prices and household income in accessible datasets. This is one of the main reasons we use the mean values to indicate housing affordability in China. A second reason is based on our review of the $10^{\text {th }}-13^{\text {th }}$ Annual Demographia International Housing Affordability Survey: 2014-2017 [49-52], which discusses the data-collection differences between Asian countries, especially those in East Asia, and Western countries.

In East Asian countries, publicly-used data is preferred in typical approaches rather than median values. The Housing Affordability Survey supports this argument and compares the index with other countries all around the world. For example, Japan and Hong Kong are also selected as survey cases in the collected list. Based on the discussion in the Survey, we can use the average values of housing prices and household income to show the housing affordability index as well, because we use both of the average values, although there are some outliers that impact the value calculation. However, 
when we have both average values together and make a division, the outliers will be offset and the index will still show the essential picture, as we expect.

Table 2. Demographic and Economic Features of the Three Cities.

\begin{tabular}{cccccc}
\hline City & $\begin{array}{c}\text { Population Density } \\
\text { (People/Square Mile) }\end{array}$ & $\begin{array}{c}\text { Household } \\
\text { Size }\end{array}$ & $\begin{array}{c}\text { Housing Price } \\
\text { (\$/Square Foot) }\end{array}$ & $\begin{array}{c}\text { Household } \\
\text { Income (\$) }\end{array}$ & $\begin{array}{c}\text { Housing } \\
\text { Affordability }\end{array}$ \\
\hline Beijing & 23,210 & 2.9 & 272 & 28,500 & 13.9 \\
Tianjin (including & 8213 & 2.8 & 181 & 23,232 & 8.4 \\
Binhai New Area) & 14,075 & 3.2 & 270 & 29,000 & 9.2 \\
Guangzhou & & 3.2 & \\
\hline
\end{tabular}

Sources: China Real Estate Statistics Yearbook, $10^{\text {th }}-13^{\text {th }}$ Annual Demographia International Housing Affordability Survey: 2014-2017 [49-52]; Note: Since housing prices and household income in China's cities are illustrated in RMB currency, it is necessary to change the amounts into U.S. Dollars. The exchange rate between RMB and the U.S. Dollars has significantly changed during recent decades. The amount in this table utilized the current exchange rate to convert the housing price and household income into U.S. Dollars for easy and efficient comparison.

Specifically, it is much easier to illustrate the housing affordability problems through the housing price-to-income ratio. Housing-Price to Income (HPI), Affordable Housing Investment (AHI) and Rations of Affordable Housing ( $\mathrm{RAH}$ ) are the main indicators used to compare the outcome of housing policy and development. Figures 1-3 show those indicators in Beijing, Guangzhou, and Tianjin. HPI assumes that housing price to income is the elementary affordability measure for housing in some selected areas at the city, regional, or national levels. The ratio is calculated by the forum, which indicates the ratio of mean house prices to average of familial disposable income. If the HPI is high, the individuals of the given area will find it difficult to buy a house. AHI is the absolute investment amount in affordable housing. This is one popular way to check government investment on affordable housing, as the main resources for affordable housing development are derived from public budgeting in China. Hence, the higher the AHI, the higher the investment in affordable housing. $\mathrm{RAH}$ is the proportion in the total housing provision represented by affordable housing (Lines 440-441). This ratio indicates to the selected municipal governments whether to pay more attention to affordable housing development or to promote a real estate boom. Thus, the higher the RAH, the higher the priority placed by local government on affordable housing projects.

As mentioned above, a higher HPI means more dramatic inflation of housing prices, which implies more, and more severe, housing affordability problems in the selected areas. The local government has to enforce some interventions to regulate housing-price inflation and maintain sustainable development in the area. AHI is the measurement of absolute amount of affordable housing investment, more AHI implies more attention has been paid by the local government. RAH is a ratio not only focusing on amount of investment in affordable housing but also taking total housing provision (entire housing market) into account. So, this ratio can further imply the housing policy and priority in the city in addition to the absolute amount [53].

Based on literature from a series of housing studies, HPI is one of the main indices evaluating housing-price inflation and housing affordability, rather than marketization. In this sense, changes in HPI imply the severity of the housing affordability problem in the selected areas. Evaluating the market orientation entails other measurements such as market transactions, and establishment of property rights.

To some extent, more investment in affordable housing would be an effective way to control the inflation of housing price, as affordable housing units are able to fulfill the needs of local residents who cannot afford the market-price housing. However, there is no statistically-significant relationship between HPI and AHI based on the data we collected. This is because the HPI keeps increasing (by a different percentage) even though the AHI increased. If we could verify more variables to build up a model to explain the change of HPI and AHI, a future article could focus on developing a measurement for housing affordability. 
According to Figure 1, all of the three cities have experienced severe housing affordability problems in the first decades of the 21th century. The price-to-income ratios of the three cities are over five and the trends of these ratios have increased overall. Surprisingly, Beijing had the highest ratio among the three cities, with a housing-price-to-income ratio of over 11.

Moreover, the shapes of this figure in these Chinese cities reveal interesting features of housing prices and household income. Before 2004, housing-price-to-income ratio kept declining even though housing prices in Chinese cities increased. This demonstrates that household income grew faster than the inflation of housing prices in the Chinese metropolitan areas over the first several years. However, this situation shifted after 2005. Housing prices experienced exponential inflation from 2005 to 2010 in China, although the growth of household income in these Chinese cities obtained a relatively smooth increasing trend. Based on the indications of Figure 1, the price-to-income ratio in the three Chinese cities has maintained an increase since 2005, and housing prices experienced exponential inflation from 2005 to 2010 in China. Although the ratio slightly declined at the beginning of the 2008 global financial crisis, housing prices returned to inflation the following year and continued to inflate dramatically after 2010, making the ratios higher than those before the global financial crisis.

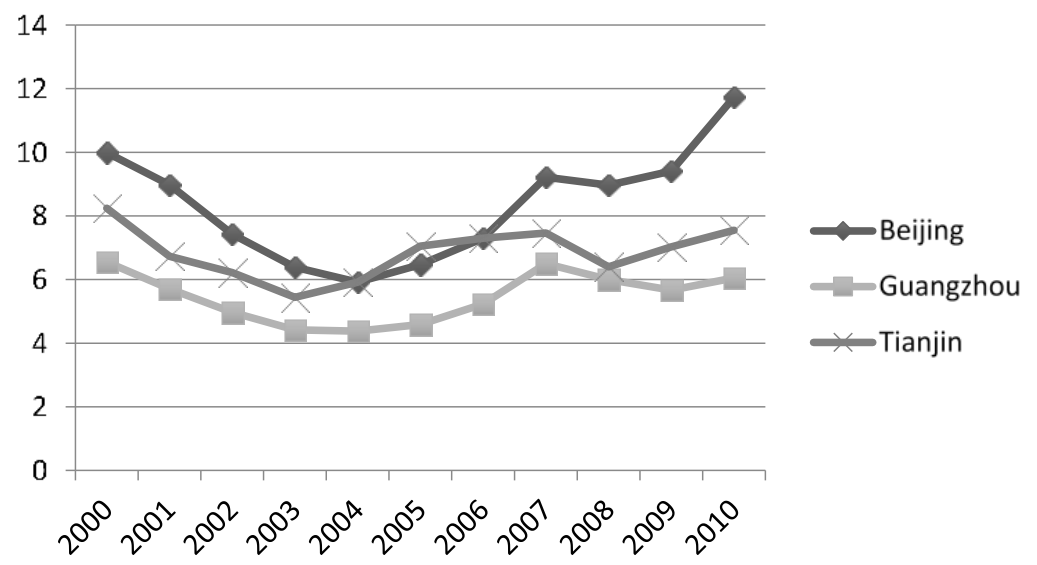

Figure 1. Housing-Price-to-Income Ratio of the Three Cities.

As mentioned above, the three cities have experienced severe housing affordability problems because of housing-price inflation. The municipal governments in these cities paid more attention to developing affordable housing units in order to provide local dwellers with more affordable (decent) housing. Figure 2 shows that, except for Beijing, the cities have increased investment in affordable housing. Beijing, which placed considerable emphasis on affordable housing in the first few years, experienced three major shifts in the development of its affordable housing projects. The city kept enhancing the projects from 2000 to 2003, whereas a major downturn was experienced after 2004. The downward trend continued until 2007. Consequently, the Beijing Municipal Government restarted its agenda to promote affordable housing. However, this promotion did not last long and a third downturn happened in 2010. On the other hand, Tianjin experienced continuous growth in affordable housing investment. Compared to Beijing and Tianjin, Guangzhou intended to maintain its investment in affordable housing programs along with gradual increases. However, the amount of investment in Guangzhou was much lower than those in Beijing and Tianjin, despite a similar population size (Beijing: 20 Million, Tianjin: 15 Million; Guangzhou: 18 Million). 


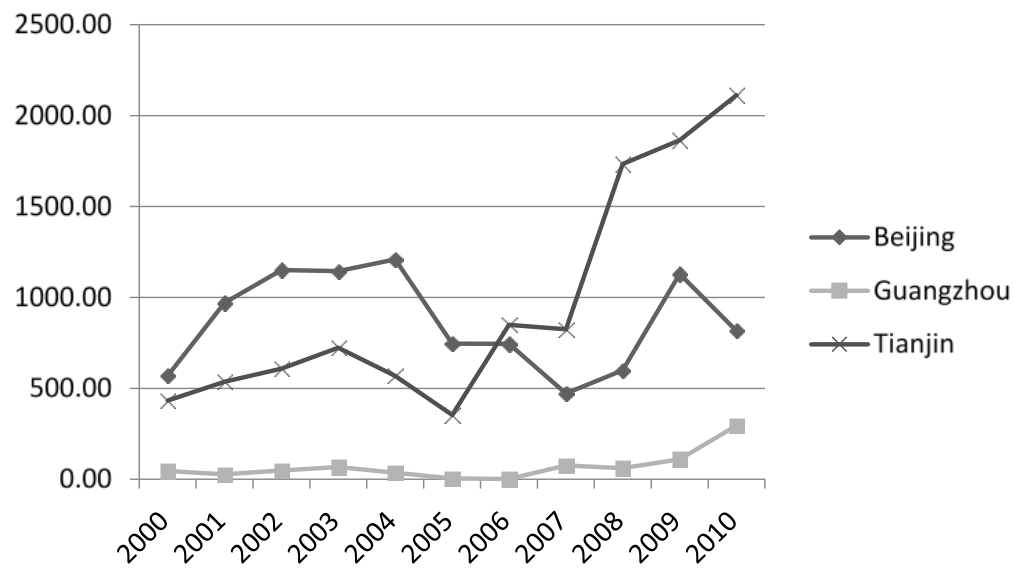

Figure 2. Affordable Housing Investment.

A further indication of the effectiveness of affordable housing policies and programs in these three cities in China can be cited. This is the amount of affordable housing as a proportion of the total housing provision. Based on Figure 3, the proportion of affordable housing in the Beijing and Tianjin local housing markets decreased. In the beginning of the 21st century, the Beijing Municipal Government promoted affordable housing programs and increased the production of new affordable housing to more than 10 percent of total new housing. However, the proportion decreased to less than 5 percent in 2010 along with the decline in affordable housing investment. Even though the proportion of affordable housing of Tianjin remained the highest among the three Chinese cities, it dropped from 30 percent to approximately 20 percent. Generally speaking, affordable housing development in Beijing and Tianjin gradually decreased compared to market-rate housing investment.

The development of affordable housing in Guangzhou increased slightly between 2009 and 2010, although the proportion remained less than 5 percent of total housing. If the trend over the entire ten years is taken into account, the investment in affordable housing by the Guangzhou Municipal Government was no higher than 5 percent of the total residential housing investment. It is worthwhile to note that in general, Guangzhou placed minimal emphasis on affordable housing development and invested a limited amount in related programs or projects.

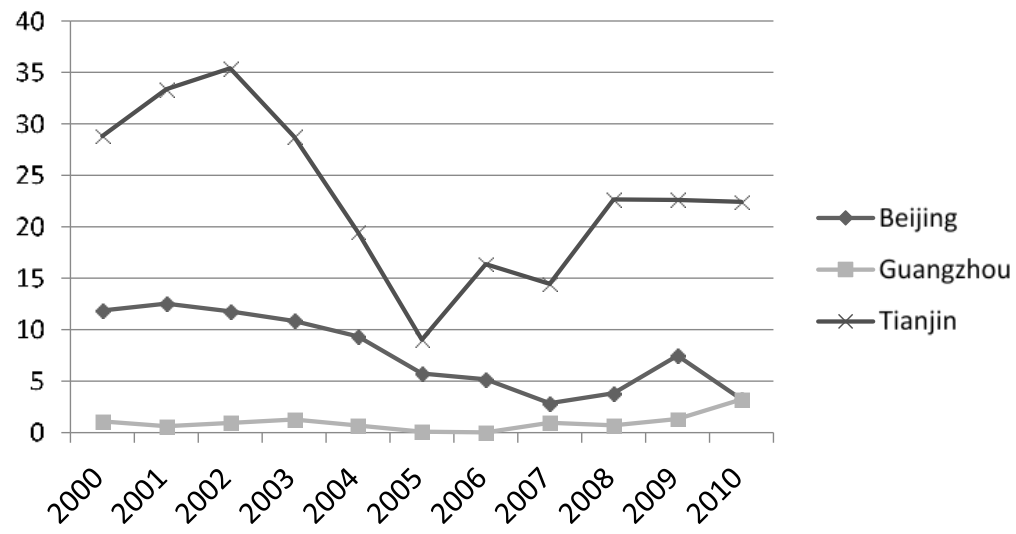

Figure 3. Ratios of Affordable Housing.

\section{Discussion and Conclusion}

Based on the above analysis, we conclude that housing affordability problems are closely correlated to household income and housing prices. The relationship has been indicated in the previous section on housing affordability measurements. For these three Chinese cities, housing-price 
inflation has exerted a significant negative impact on housing-affordability issues. This is particularly true for these three cities, when the boom of the housing market caused substantial inflation of housing prices since 2006.

In terms of the definition of housing affordability, all of these cities' policy documents expressed "affordability" mainly based on income standards and assets level. This "absolute value" measurement has restricted the coverage of their affordable housing to low-income households as the sole target group [54]. However, migrants, young workers, and the "sandwich class" are barely mentioned in local affordable housing policies, nor the people with special housing needs such as the elderly population and people with disabilities has been mentioned [47]. This biased affordability measurement and discriminatory housing policy excludes a number of underprivileged groups who also encounter the pressure of affording housing and are in urgent need of affordable housing. To achieve the goals of affordable housing and sustainable development, the municipal administration and urban policy should note that the coverage of the policies ought to improve housing situations for most local residents who experience housing affordability problems [55].

In addition, the consistency of affordable housing provision is of crucial importance in dealing with housing affordability problems despite the severe situation in relation to affordability of housing. Based on the investigation of the eleven-year trends of the three cities, the main problems of affordable housing policies in Chinese cities have apparently been dealt with a series of short-term programs, such as the Economic and Comfortable Housing (ECH), and The Housing Provident Fund (HPF), and Cheap Rental Housing (CRH) programs, in order to enhance economic growth [40]. Thus, the investment in affordable housing projects has shifted significantly owing to changes in the economy [56].

Due to the huge financial burden incurred with the promotion of affordable housing programs, many local governments become reluctant to exert effort to develop affordable housing in the long run. Almost all of the funding for affordable housing projects comes from local governments, while there is barely any essential financial support from the Chinese central government [31]. Local fundraising innovations for affordable housing, despite being discussed frequently on social media, are still underdeveloped and considered a "forbidden zone" in housing projects. Thus, it would be a huge challenge to maintain such tremendous scale and investment in affordable housing developments to ensure the sustainable development of Chinese cities in the coming decades.

Because the development of affordable housing is a string of huge and long-lasting projects in metropolitan areas, the collaboration between public agencies and NPOs or civic groups is critically important. In China, there is only one housing security (reform) department in charge of affordable housing construction, maintenance, and allocation. This public authority is merely an office or branch within the municipal bureau of Housing and Urban-Rural Development (HURD), which is tasked with tackling the development issues of affordable housing as well as those of market-rate housing [57]. Thus, housing security (reform) departments are not authorized to hold any public hearings or even forums to discuss affordable housing issues with different stakeholders or third-party groups, but are supervised by HURD and follow orders. This aggravates the problem due to insufficient responsiveness to the needs of residents and implementation of policies.

Author Contributions: All authors contributed extensively to the various phases of the work presented in this paper.

Conflicts of Interest: The authors declare no conflict of interest.

\section{References}

1. Bratt, R.G. Rebuilding a Low-Income Housing Policy; Temple University Press: Philadelphia, NY, USA, 1989.

2. Linneman, P.D.; Megbolugbe, I.F. Housing affordability: Myth or reality? Urban Stud. 1992, $29,369-392$. [CrossRef]

3. Wang, Y.P.; Murie, A. The new affordable and social housing provision system in China: Implications for comparative housing studies. Int. J. Hous. Policy 2011, 11, 237-254. [CrossRef] 
4. Huang, Y.; Clark, W.A. Housing tenure choice in transitional urban China: A multilevel analysis. Urban Stud. 2002, 39, 7-32. [CrossRef]

5. Hulchanski, J.D. The concept of housing affordability: Six contemporary uses of the housing expenditure-to-income ratio. Hous. Stud. 1995, 10, 471-491. [CrossRef]

6. Katz, B.; Turner, M.A.; Brown, K.D.; Cunningham, M.; Sawyer, N. Rethinking Local Affordable Housing Strategies: Lessons from 70 Years of Policy and Practice; The Brookings Institute: Washington, DC, USA, 2003.

7. Goodman, J. Housing Affordability in the United States: Trends, Interpretations, and Outlook; Report to the Millennial Housing Commission; Millennial Housing Commission: Washington, DC, USA, 2001.

8. Huang, Y. Housing markets, government behaviors, and housing choice: A case study of three cities in China. Environ. Plan. A 2004, 36, 45-68. [CrossRef]

9. Kuang, W.; Li, X. Does China face a housing affordability issue? Evidence from 35 cities in China. Int. J. Hous. Mark. Anal. 2012, 5, 272-288. [CrossRef]

10. Mostafa, A.; Wong, F.K.; Hui, C.M. Relationship between housing affordability and economic development in mainland China-Case of Shanghai. J. Urban Plan. Dev. 2006, 132, 62-70. [CrossRef]

11. Maclennan, D.; Williams, R. Affordable Housing in Britain and America; Joseph Rowntree Foundation: York, UK, 1990.

12. Basolo, V.; Scally, C.P. State innovations in affordable housing policy: Lessons from California and New Jersey. Hous. Policy Debate 2008, 19, 741-774. [CrossRef]

13. Stone, M.E. What is housing affordability? The case for the residual income approach. Hous. Policy Debate 2006, 17, 151-184. [CrossRef]

14. Sazama, G.W. Lessons from the history of affordable housing cooperatives in the United States: A case study in American affordable housing policy. Am. J. Econ. Sociol. 2000, 59, 573-608. [CrossRef]

15. Goetz, E.G. Shelter Burden: Local Politics and Progressive Housing Policy; Temple University Press: Philadelphia, NY, USA, 1993.

16. Rosen, M.; Sullivan, W. From Urban Renewal and Displacement to Economic Inclusion: San Francisco Affordable Housing Policy 1978-2012; PRRAC: Washington, DC, USA, 2012.

17. Chen, J.; Yang, Z.; Wang, Y.P. The new Chinese model of public housing: A step forward or backward? Hous. Stud. 2014, 29, 534-550. [CrossRef]

18. Zou, G.L.; Chau, K.W. Determinants and sustainability of house prices: The case of Shanghai, China. Sustainability 2015, 7, 4524-4548. [CrossRef]

19. Jabareen, Y.R. Sustainable urban forms their typologies, models, and concepts. J. Plan. Educ. Res. 2006, 26, 38-52. [CrossRef]

20. Yeung, S.C.W.; Howes, R. The role of the housing provident fund in financing affordable housing development in China. Habitat Int. 2006, 30, 343-356. [CrossRef]

21. Huang, Y. Low-income housing in Chinese cities: Policies and practices. China Q. 2012, 212, 941-964. [CrossRef]

22. National Bureau of Statistics of China. China Index Academy China Real Estate Statistics Yearbook. Available online: http:/ / tongji.cnki.net/kns55/Navi/HomePage.aspx?id=N2012020069\&name=YNEIO\& floor=1 (accessed on 1 April 2017).

23. National Bureau of Statistics of China. China Statistic Yearbook. Available online: http://data.stats.gov.cn/ easyquery.htm?cn=C01 (accessed on 1 April 2017).

24. Hui, E.C.; Wong, F.K. Affordable housing in China. Habitat Int. 2006, 30, 275-276. [CrossRef]

25. Hamidi, S.; Ewing, R.; Renne, J. How Affordable Is HUD Affordable Housing? Hous. Policy Debate 2016, 26, 437-455. [CrossRef]

26. Lin, W.; Raman, K.K. The housing value-relevance of governmental accounting information. J. Account. Public Policy 1998, 17, 91-118. [CrossRef]

27. Leung, C.K.Y.; Sarpça, S.; Yilmaz, K. Public housing units vs. housing vouchers: Accessibility, local public goods, and welfare. J. Hous. Econ. 2012, 21, 310-321. [CrossRef]

28. Mulliner, E.; Malys, N.; Maliene, V. Comparative analysis of MCDM methods for the assessment of sustainable housing affordability. Omega 2016, 59, 146-156. [CrossRef]

29. Whitehead, C.M. Planning policies and affordable housing: England as a successful case study? Hous. Stud. 2007, 22, 25-44. [CrossRef] 
30. Deng, L.; Shen, Q.; Wang, L. The emerging housing policy framework in China. J. Plan. Lit. 2011, 26, 168-183. [CrossRef]

31. Wang, Y.P. Urban housing reform and finance in China a case study of Beijing. Urban Aff. Rev. 2001, 36, 620-645. [CrossRef]

32. Yang, Z.; Shen, Y. The affordability of owner occupied housing in Beijing. J. Hous. Built Environ. 2008, 23, 317-335. [CrossRef]

33. Zou, Y. Contradictions in China's affordable housing policy: Goals vs. structure. Habitat Int. 2014, 41, 8-16. [CrossRef]

34. Schwartz, A.F. Housing Policy in the United States; Routledge: London, UK, 2014.

35. Cohen, R.; Wardrip, K. Should I Stay or Should I Go? Exploring the Effects of Housing Instability and Mobility on Children; Center for Housing Policy: Washington, DC, USA, 2011.

36. Rosenheck, R.; Kasprow, W.; Frisman, L.; Liu-Mares, W. Cost-effectiveness of supported housing for homeless persons with mental illness. Arch. Gen. Psychiatry 2003, 60, 940-951. [CrossRef] [PubMed]

37. Mueller, E.J.; Tighe, J.R. Making the case for affordable housing: Connecting housing with health and education outcomes. J. Plan. Lit. 2007, 21, 371-385. [CrossRef]

38. Anderson, L.M.; Charles, J.S.; Fullilove, M.T.; Scrimshaw, S.C.; Fielding, J.E.; Normand, J.; Task Force on Community Preventive Services. Providing affordable family housing and reducing residential segregation by income: A systematic review. Am. J. Prev. Med. 2003, 24, 47-67. [CrossRef]

39. Maqbool, N.; Ault, M.; Viveiros, J. The Impacts of Affordable Housing on Health: A Research Summary; Center for Housing Policy: Washington, DC, USA, 2015.

40. Tighe, J.R. Public opinion and affordable housing: A review of the literature. J. Plan. Lit. 2010, 25 , 3-17. [CrossRef]

41. Black, J.T.; Hoben, J.E. Land price inflation and affordable housing. Urban Geography. 1985, 6, $27-47$. [CrossRef]

42. Zhu, Y.P. Policy networks and policy paradigm shifts: Urban housing policy development in China. J. Contemp. China 2013, 22, 554-572. [CrossRef]

43. Logan, J.R.; Fang, Y.; Zhang, Z. The winners in China's urban housing reform. Hous. Stud. 2010, 25, $101-117$. [CrossRef] [PubMed]

44. Lin, Y.; De Meulder, B.; Cai, X.; Hu, H.; Lai, Y. Linking social housing provision for rural migrants with the redevelopment of 'villages in the city': A case study of Beijing. Cities 2014, 40, 111-119. [CrossRef]

45. Dang, Y.; Liu, Z.; Zhang, W. Land-based interests and the spatial distribution of affordable housing development: The case of Beijing, China. Habitat Int. 2014, 44, 137-145. [CrossRef]

46. Liu, R.; Wong, T.C. The allocation and misallocation of economic housing in Beijing: Target groups versus market forces. Habitat Int. 2015, 49, 303-315. [CrossRef]

47. Zhang, Y.; Fang, K. Politics of housing redevelopment in China: The rise and fall of the Ju'er Hutong project in inner-city Beijing. J. Hous. Built Environ. 2003, 18, 75-87. [CrossRef]

48. Chen, J.; Stephens, M.; Man, Y. The Future of Public Housing; Springer: New York, NY, USA, 2014.

49. Demographia (2014) 10th Annual Demographia International Housing Survey. Available online: http://www. demographia.com/dhi2014.pdf (accessed on 1 April 2017).

50. Demographia (2015) 11th Annual Demographia International Housing Survey. Available online: http://www. demographia.com/dhi2015.pdf (accessed on 1 April 2017).

51. Demographia (2016) 12th Annual Demographia International Housing Survey. Available online: https:/ /assets. documentcloud.org/documents/2697405/Demographia-2016.pdf (accessed on 1 April 2017).

52. Demographia (2017) 13th Annual Demographia International Housing Survey. Available online: http://www. demographia.com/dhi.pdf (accessed on 1 April 2017).

53. Leung, C. Macroeconomics and housing: A review of the literature. J. Hous. Econ. 2004, 13, $249-267$. [CrossRef]

54. Chen, J.; Guo, F.; Wu, Y. One decade of urban housing reform in China: Urban housing price dynamics and the role of migration and urbanization, 1995-2005. Habitat Int. 2011, 35, 1-8. [CrossRef]

55. National Bureau of Statistics of China. China Statistic Yearbook 1999-2011. 2000-2012. Available online: http:/ /www.stats.gov.cn/english/statisticaldata/AnnualData/ (accessed on 1 April 2017). 
56. Shi, W.; Chen, J.; Wang, H. Affordable housing policy in China: New developments and new challenges. Habitat Int. 2016, 54, 224-233. [CrossRef]

57. Niu, Y. The performance and problems of affordable housing policy in China: The estimations of benefits, costs and affordability. Int. J. Hous. Mark. Anal. 2008, 1, 125-146. [CrossRef] 